Reprod. Nutr. Dévelop., 1987, 27 (6), 1041-1051.

\title{
Effects of dietary glucogenic amino acid supplementation on growth performance, body composition and plasma free amino acid levels in genetically lean and fat chickens
}

\author{
P. A. GERAERT, B. LECLERCQ, M. LARBIER
}

Station de recherches Avicoles, I.N.R.A., Nouzilly, 37380 Monnaie, France.

Summary. Two experiments were conducted to investigate the effects of pair-feeding, nutritional status (fasting $v s$ feeding ad libitum) and supplementing diets with alanine $(2 \mathrm{~g} / \mathrm{kg})$, threonine $(2 \mathrm{~g} / \mathrm{kg})$, glutamic acid $(5 \mathrm{~g} / \mathrm{kg})$ and arginine $(5 \mathrm{~g} / \mathrm{kg})$ on growth performance, body composition and free plasma amino acid levels in genetically lean (LL) or fat (FL) chickens of 4 to 7 weeks of age. When fed ad libitum, FL chickens ate more than LL birds and showed higher lipid and protein gains. However, when pair-fed, FL birds exhibited increased lipid retention but lower protein gain. Growth performance and body composition were not significantly affected by the addition of glucogenic amino acids to the diets. However, amino acid supplementation slightly improved food to gain ratios but depressed gross energy and protein efficiencies in both lines. FL chickens had lower plasma levels of most glucogenic amino acids and higher levels of branched-chain and sulphur amino acids than LL birds, irrespective of diet and nutritional status. These results are discussed in relation to hormonal characteristics of $\mathrm{FL}$ and $\mathrm{LL}$ birds.

\section{Introduction.}

The modern broiler, as a consequence of selection for a rapid growth rate, is becoming increasingly prone to fatness. To investigate the physiological control of fat deposition, a fat line (FL) and a lean line (LL) of broiler chickens have been obtained by divergent selection for high or low abdominal fat content but similar live body weight at 9 weeks of age (Leclercq et al., 1980). Previous studies (Touchburn et al., 1981 ; Leclercq and Saadoun, 1983; Simon and Leclercq, 1983) have shown that the difference in fat content between these lines cannot be account for by changes in food consumption, maintenance energy requirement, digestive utilization of dietary energy or body temperature. However, the FL gains less dietary nitrogen (Leclercq, 1983) and more energy as fat than the LL (Geraert et al., 1987). Furthermore, in fasted birds total plasma free amino acid levels are lower in the FL than in the LL because of significantly lower levels of the glucogenic amino acids threonine, alanine, glutamic acid and arginine (Larbier and Leclercq, 1983). Therefore, the metabolism of dietary amino acids, 
and in particular that of glucogenic amino acids, may differ between these two lines, thereby causing differences in growth performance and body composition.

The present study was carried out in order to investigate the effects of glucogenic amino acid supplementation on growth performance, body composition (especially protein retention) and plasma free amino acid levels in FL and $\mathrm{LL}$ chickens under different nutritional conditions.

\section{Materials and methods.}

\section{Experiment 1}

Male chickens from the seventh generation of the FL and LL lines (Leclercq et al., 1980) were used. The birds were housed in floor pens from hatching to 4 weeks of age. They were fed a complete diet containing $220 \mathrm{~g}$ protein and 12.7 MJ M.E. per kg.

When the birds were 4 weeks old, twelve from each line were slaughtered and plucked and the carcasses were kept for chemical analysis. Twenty LL and forty FL birds were then transferred to individual cages in a environmentcontrolled room $\left(25{ }^{\circ} \mathrm{C}\right.$ and $70 \%$ relative humidity) where they remained until 7 weeks of age. The lighting regimen was $16 \mathrm{~L}: 8 \mathrm{D}$. Twenty birds of each line were fed ad libitum and a further $20 \mathrm{FL}$ birds were pair-fed daily against the LL birds. FL birds were chosen with a mean weight $13 \%$ greater than that of LL birds to give a similar lean mass according to previous results (Saadoun and Leclercq, 1983 ; Leclercq, 1983). All birds received a control maize-soyabean meal diet containing 13.8 MJ ME and $180 \mathrm{~g}$ protein, $9.7 \mathrm{~g}$ lysine and $7.2 \mathrm{~g}$ sulphur amino acids per $\mathrm{kg}$ or the same diet supplemented with $2 \mathrm{~g}$ DL-alanine, $2 \mathrm{~g} \mathrm{~L}$ threonine, $5 \mathrm{~g} \mathrm{~L}$-glutamic acid and $5 \mathrm{~g} \mathrm{~L}$-arginine per $\mathrm{kg}$. The measured amino acid composition of the diets is given in table 1. Daily food consumption and initial and final body weights were measured.

\section{TABLE 1}

Measured amino acid composition of the basal diets $(\mathrm{g} / \mathrm{kg}$ of diet).

\begin{tabular}{ccc}
\hline Amino acid & Experiment 1 & Experiment 2 \\
\hline ASP & 16.0 & 17.8 \\
THR & 9.8 & 9.7 \\
SER & 9.6 & 10.3 \\
GLU & 33.4 & 36.2 \\
GLY & 7.5 & 7.5 \\
ALA & 9.8 & 10.4 \\
VAL & 8.8 & 8.8 \\
ILEU & 7.6 & 7.3 \\
LEU & 17.0 & 18.0 \\
TYR & 7.2 & 7.4 \\
PHE & 9.1 & 10.0 \\
LYS & 10.0 & 10.1 \\
HIS & 5.1 & 5.2 \\
ARG & 12.0 & 12.7 \\
\hline
\end{tabular}


At 6 weeks of age (fed birds) and 7 weeks of age (birds fasted overnight), blood samples were taken from the wing vein using an heparinized syringe. Blood samplings were made at 10 a.m., $2 \mathrm{~h}$ after " lights on " and at 1 week interval to avoid stress or sampling effects on blood composition. Samples were immediately chilled and centrifuged. Portions of plasma from each of three chickens were then mixed and stored at $-20^{\circ} \mathrm{C}$. Free amino acids were extracted with sulfosalicylic acid and determined with a LKB 4400 auto-analyser (Larbier et al., 1982). Plasma glucose and uric acid were measured with a glucose analyzer (model 2, Beckman Instruments Palo Alto CA).

At 7 weeks of age, all birds were slaughtered and plucked. Carcasses were minced twice and freeze-dried. Celite (silicon dioxide) was added before grinding to prevent lipid loss. The lipids were extracted in a Soxhiet apparatus. Protein contents of carcasses and diets were determined by the macro-Kjeldahl method. Energy contents of samples were measured using an adiabatic bomb calorimeter (Gallenkamp).

\section{Experiment 2}

A second trial was conducted in order to confirm the results of the first experiment. The only difference in the experimental design was the suppression of the pair-fed FL group.

Thirty-six male chickens of the FL and LL (F7 generation) were used. Husbandry conditions were as in Exp. 1. As in the first experiment, FL birds with a similar lean mass to that of LL birds were used as experimental subjects. Half (18) of the animals from each line were fed ad libitum on a control diet similar to that described in experiment 1 . The remaining animals were fed ad libitum on the amino acid-supplemented diet described in table 1. Blood samples were taken as previously but analyzed individually. No carcass analysis was performed.

Statistical analyses of results were carried out by factorial analysis of variance (Snedecor and Cochran, 1956).

\section{Results.}

\section{1. - Growth performance and body composition (tables 2 and 3).}

In both experiments, when fed ad libitum, FL birds ate more than LL birds and had higher body weight gains. However, FL birds exhibited a higher food to gain ratio between 4 and 7 weeks of age (2.23 vs 2.05 respectively; control diet, experiment 1). When $F L$ and LL birds were pair fed, FL birds exhibited lower weight gains and a higher food to gain ratios than $L L$ birds $(2.26$ vs 2.05 , control diet). The addition of glucogenic amino acids did not significantly affect growth performance but tended to improve food to gain ratio in both lines $(P<0.01$, experiment 2). Surprisingly supplementation decreased food intake in experiment 1 , but not in experiment 2 . Moreover, the higher mean body weight of FL and LL chickens at 4 weeks of age in experiment 2 labout $200 \mathrm{~g}$ compared with 


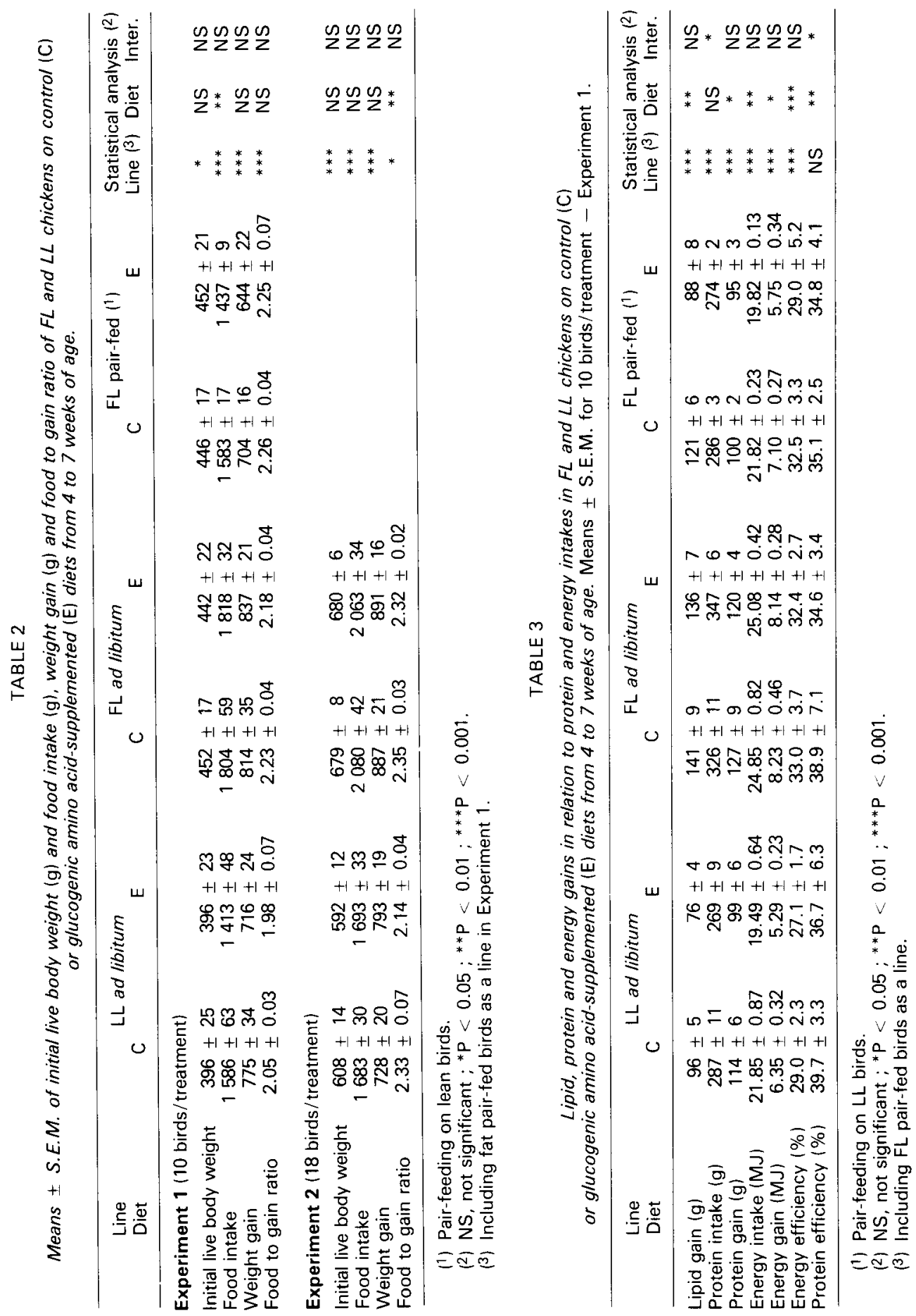


experiment 1) did not affect growth performance to a large extent although an overall decrease in food efficiency was observed.

When fed ad libitum, FL birds accumulated more body lipids than LL chickens $(+47 \%$, control and $+79 \%$, supplemented diet). Pair-fed FL birds exhibited a higher lipid gain $(+26 \%$ and $+16 \%$, control and experimental diet respectively) than LL chickens but a lower protein gain $(-12 \%$, control and $-4 \%$ supplemented diet). Energy gross efficiency was, therefore, significantly higher in the FL than the LL but protein efficiency was lower.

Supplementation with glucogenic amino acids decreased lipid gain in pair-fed $\mathrm{LL}$ and $\mathrm{FL}$ birds irrespective of differences in energy intake. Moreover, energy and protein efficiencies were reduced by amino acid addition both in pair-fed and ad libitum fed birds.
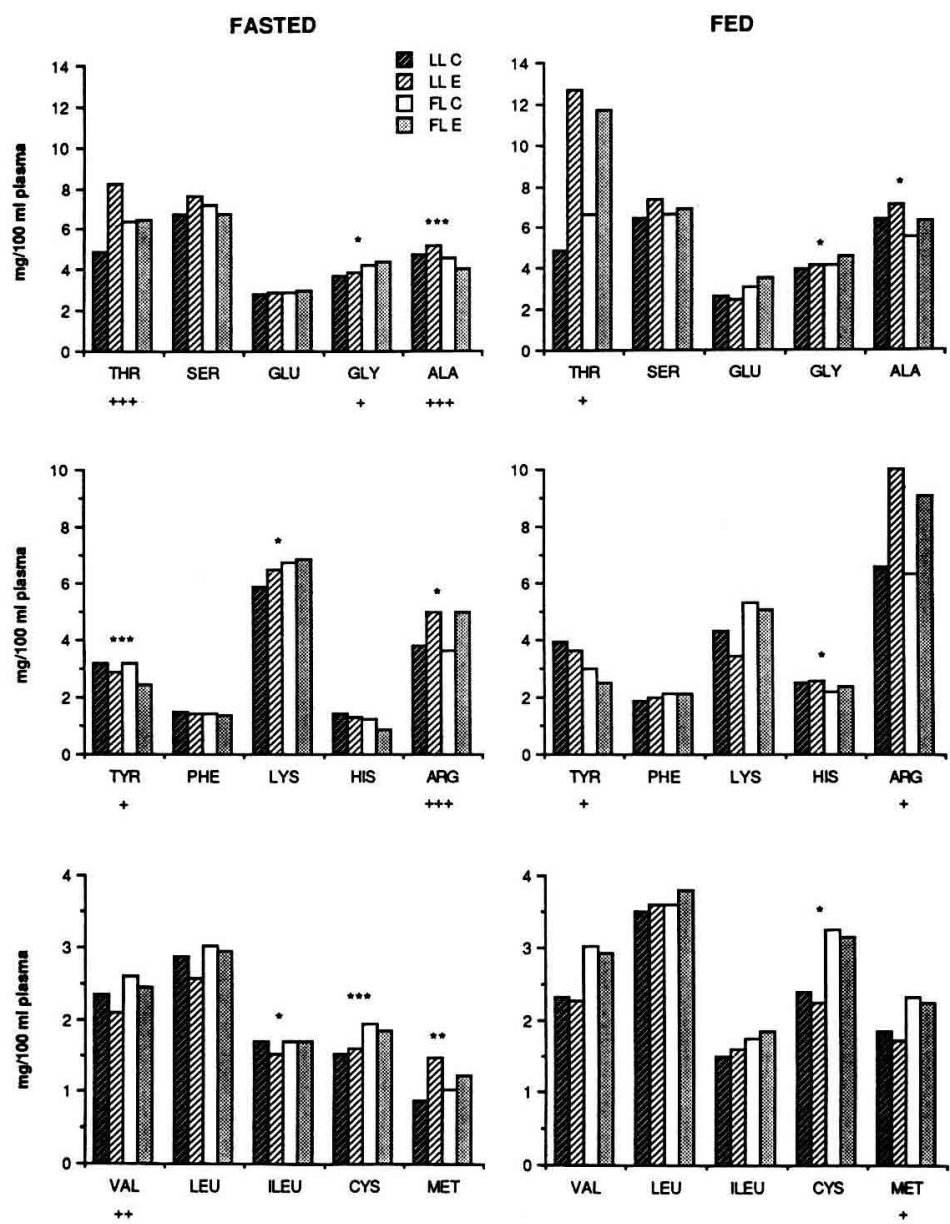

FIG. 1. - Plasma levels of free amino acids in FL and LL male chickens fasted (16 hours) or fed ad libitum on a control (C) or glucogenic amino acid-supplementated (E) diet. Experiment 1.

Line comparison: ${ }^{*} \mathrm{P}<0.05 ;{ }^{* *} \mathrm{P}<0.01 ;{ }^{* *} \mathrm{P}<0.001$.

Diet comparison: $+\mathrm{P}<0.05 ;++\mathrm{P}<0.01 ;+++\mathrm{P}<0.001$. 
2. - Free plasma amino acids, glucose and uric acid (table 4, Fig. 1 and 2).

Uric acid levels did not differ between the FL and LL (table 4). Fasted FL birds had significantly lower plasma glucose levels than LL birds $(1.97 \mathrm{vs}$ $2.25 \mathrm{~g} / \mathrm{l}$ ). Feeding doubled uric acid levels in both lines and increased plasma glucose levels in the FL but not in the LL. Supplementation of diets with amino acids did not affect any of these parameters.

FASTED
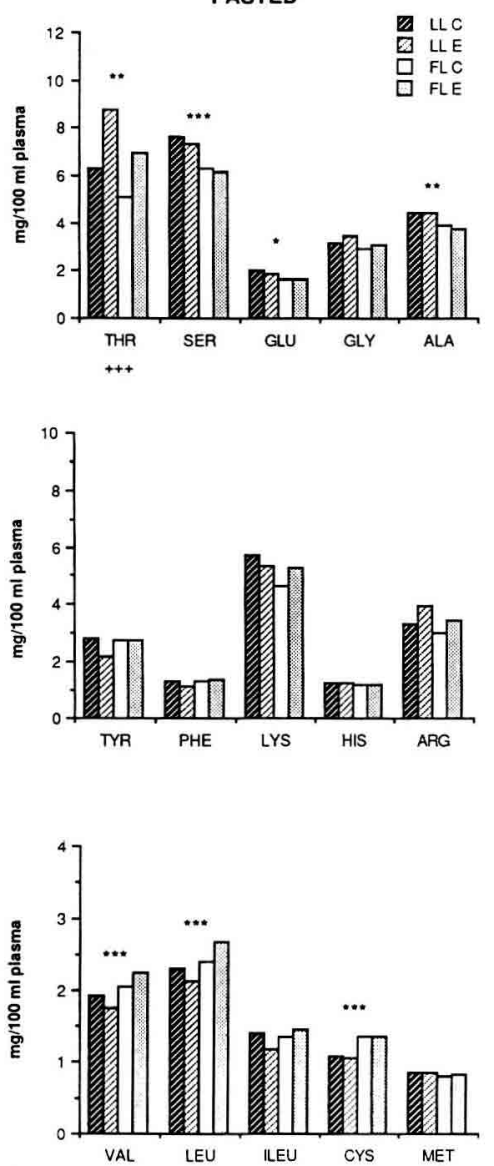

FED
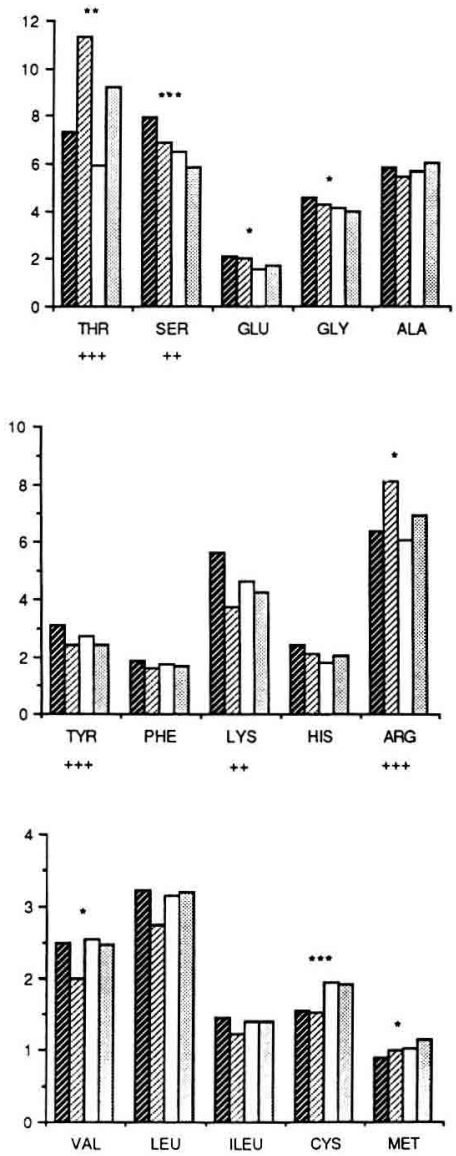

FIG. 2. - Plasma levels of free amino acids in FL and $L L$ male chickens fasted (16 hours) or fed ad libitum on a control (C) or glucogenic amino acid-supplementated (E) diet. Experiment 2.

Line comparison : ${ }^{*} \mathrm{P}<0.05 ;{ }^{*} \mathrm{P}<0.01 ;{ }^{* *} \mathrm{P}<0.001$.

Diet comparison : $+\mathrm{P}<0.05 ;++\mathrm{P}<0.01 ;+++\mathrm{P}<0.001$.

Irrespective of the nutritional status or diet, fat chickens displayed lower $(\mathrm{P}<0.05)$ total plasma free amino acid levels than lean birds $(-10 \%$ and $-7 \%$, fasted and fed chickens respectively). Some plasma glucogenic amino acid levels were significantly decreased in FL birds compared to those of LL 
TABLE 4

Plasma glucose $(\mathrm{g} / \mathrm{l})$, uric acid $(\mathrm{mg} / \mathrm{l})$, total free amino acid $(\mathrm{mg} / 100 \mathrm{ml}$ plasma) levels in $\mathrm{FL}$ and $L L$ chickens : effect of nutritional status and glucogenic amino acid supplementation (Experiment 2). Means \pm S.D.

\begin{tabular}{|c|c|c|c|c|c|c|c|}
\hline \multirow{2}{*}{$\begin{array}{l}\text { Line } \\
\text { Diet }\end{array}$} & \multicolumn{2}{|c|}{ LL } & \multicolumn{2}{|c|}{ FL } & \multicolumn{3}{|c|}{ Statistical analysis (1) } \\
\hline & Control & Supplemented & Control & Supplemented & Line & Diet & Interact. \\
\hline \multicolumn{8}{|l|}{ Fasted } \\
\hline $\begin{array}{l}\text { Glucose } \\
\text { Uric acid } \\
\text { Total amino acids }\end{array}$ & $\begin{aligned} 2.23 & \pm .17 \\
20 & \pm 8 \\
50.7 & \pm 6.3\end{aligned}$ & $\begin{aligned} 2.27 & \pm .15 \\
25 & \pm 8 \\
52.0 & \pm 7.4\end{aligned}$ & $\begin{aligned} 1.97 & \pm .10 \\
23 & \pm 9 \\
45.1 & \pm 5.8\end{aligned}$ & $\begin{aligned} 1.97 & \pm .16 \\
23 & \pm 12 \\
47.5 & \pm 4.9\end{aligned}$ & $\stackrel{* * *}{N S}$ & $\begin{array}{l}\text { NS } \\
\text { NS } \\
\text { NS }\end{array}$ & $\begin{array}{l}\text { NS } \\
\text { NS } \\
\text { NS }\end{array}$ \\
\hline \multicolumn{8}{|l|}{ Fed } \\
\hline $\begin{array}{l}\text { Glucose } \\
\text { Uric acid } \\
\text { Total amino acids }\end{array}$ & $\begin{aligned} 2.23 & \pm .12 \\
41 & \pm 16 \\
69.9 & \pm 10.0\end{aligned}$ & $\begin{aligned} 2.28 & \pm .10 \\
45 & \pm 17 \\
70.3 & \pm 11.2\end{aligned}$ & $\begin{aligned} 2.11 & \pm .14 \\
43 & \pm 13 \\
64.7 & \pm 10.3\end{aligned}$ & $\begin{aligned} 2.10 & \pm .09 \\
45 & \pm 11 \\
65.3 & \pm 10.1\end{aligned}$ & $\stackrel{*}{*}$ & $\begin{array}{l}\text { NS } \\
\text { NS } \\
\text { NS }\end{array}$ & $\begin{array}{l}\text { NS } \\
\text { NS } \\
\text { NS }\end{array}$ \\
\hline
\end{tabular}

(1) NS, not significant ; ${ }^{*} \mathrm{P}<0.05 ;{ }^{* *} \mathrm{P}<0.001$.

birds : alanine, histidine, tyrosine and arginine in experiment 1 and threonine, serine, glutamic acid, histidine and arginine in experiment 2. In fact, the sum of glucogenic amino acid was lower $(-10$ to $-15 \%)$ while branched-chain amino acid (valine, leucine and isoleucine) and sulphur amino acid (cystine and methionine) levels were higher in the FL than in the $L L$, irrespective of the

\section{TABLE 5}

Plasma free amino acid levels in overnight fasted $L L$ and FL chickens previous/y pair-fed on control (C) or glucogenic amino acid-supplemented (E) diets at 7 weeks of age (means \pm SEM for 10 birds per treatment) $(\mathrm{mg} / 100 \mathrm{ml}$ plasma).

\begin{tabular}{|c|c|c|c|c|c|c|c|}
\hline $\begin{array}{l}\text { Line } \\
\text { Diet }\end{array}$ & C & LL & $E$ & & C & $\mathrm{FL}$ & $E$ \\
\hline & & (1) & & (2) & & (1) & \\
\hline ASP & $0.96 \pm 0.05$ & $*$ & $0.99 \pm 0.18$ & $* * *$ & $0.80 \pm 0.02$ & & $0.94 \pm 0.05$ \\
\hline T H R & $4.86 \pm 1.19$ & & $8.23 \pm 1.37$ & & $5.41 \pm 0.94$ & & $6.76 \pm 0.79$ \\
\hline SER & $6.77 \pm 0.73$ & ${ }^{*}$ & $7.58 \pm 0.43$ & $* * *$ & $6.20 \pm 0.19$ & * & $5.24 \pm 0.42$ \\
\hline G L U & $2.80 \pm 0.05$ & & $2.85 \pm 0.17$ & & $2.35 \pm 0.09$ & ** & $3.14 \pm 0.39$ \\
\hline GLY & $3.68 \pm 0.12$ & & $3.82 \pm 0.14$ & * & $3.35 \pm 0.35$ & & $3.44 \pm 0.22$ \\
\hline$A\llcorner A$ & $4.69 \pm 0.48$ & & $5.14 \pm 0.24$ & $* * *$ & $3.55 \pm 0.20$ & & $3.52 \pm 0.12$ \\
\hline VAL & $2.36 \pm 0.34$ & & $2.09 \pm 0.28$ & & $2.27 \pm 0.17$ & & $2.21 \pm 0.04$ \\
\hline CYS & $1.53 \pm 0.24$ & & $1.61 \pm 0.40$ & ** & $2.17 \pm 0.30$ & & $2.16 \pm 0.12$ \\
\hline MET & $0.87 \pm 0.09$ & & $1.47 \pm 0.46$ & & $0.98 \pm 0.05$ & & $1.12 \pm 0.18$ \\
\hline ILEU & $1.70 \pm 0.28$ & & $1.52 \pm 0.06$ & & $1.36 \pm 0.04$ & & $1.45 \pm 0.23$ \\
\hline LEU & $2.88 \pm 0.29$ & & $2.58 \pm 0.07$ & & $2.51 \pm 0.11$ & & $2.52 \pm 0.20$ \\
\hline TYR & $3.20 \pm 0.64$ & & $2.90 \pm 0.27$ & & $3.20 \pm 0.15$ & & $2.94 \pm 0.45$ \\
\hline PHE & $1.51 \pm 0.07$ & * & $1.41 \pm 0.06$ & & $1.32 \pm 0.07$ & * & $1.51 \pm 0.13$ \\
\hline LYS & $5.87 \pm 0.66$ & & $6.49 \pm 1.35$ & & $5.05 \pm 0.61$ & & $5.76 \pm 1.41$ \\
\hline HIS & $1.46 \pm 0.26$ & & $1.31 \pm 0.30$ & & $1.09 \pm 0.09$ & & $2.83 \pm 2.56$ \\
\hline A R G & $3.80 \pm 0.84$ & & $4.97 \pm 1.06$ & & $3.65 \pm 0.17$ & & $3.24 \pm 1.62$ \\
\hline $\begin{array}{l}\text { Total free } \\
\text { amino acids }\end{array}$ & $48.91 \pm 4.15$ & * & $54.94 \pm 1.40$ & * & $45.30 \pm 1.60$ & * & $48.78 \pm 2.25$ \\
\hline
\end{tabular}

(1) Diet effect; ( $\left.{ }^{2}\right)$ Line effect.

Row means followed by an asterisk are significantly different: ${ }^{*} P<0.05,{ }^{*} P<0.01$, ***P $<0.001$. 
nutritional status or diet. Moreover, when comparing pair-fed fat and lean chickens in the fasting status, significantly lower plasma levels of glycine, serine and alanine were found in FL birds as well as higher plasma free cysteine levels (table 5).

Fed birds tended to have higher free plasma amino acid levels than fasted birds, but neither the strain of bird nor the diet influenced this effect. However, the levels of four amino acids (tyrosine, isoleucine, glutamic acid and serine) were not affected by nutritional status, and lysine levels were lower in the fed state. The addition of $\mathrm{L}$-arginine, $\mathrm{L}$-threonine, $\mathrm{DL} x$-alanine and $\mathrm{L}$-glutamic acid to the diets led to increased levels of threonine and arginine but to no changes in plasma free levels of glutamic acid and alanine in fed birds. Plasma tyrosine levels were significantly decreased by the supplemented diet in both experiments but valine and serine levels were reduced only in experiment 2.

\section{Discussion.}

As in Zucker obese rats (Radcliffe and Webster, 1978), overconsumption by FL birds (Touchburn et al., 1981) does not completely explain the difference in fattening between the $F L$ and $L L$. This fact is confirmed by the results of pairfeeding experiments (Leclercq and Saadoun, 1982 and present results). Furthermore, compared to lean birds, fat birds show higher energy and lower protein efficiencies. These results are similar to those obtained for Zucker obese rats (Chu et al., 1978 ; Pullar and Webster, 1977) but the differences are not so pronounced. Selecting birds for similar lean mass at the beginning of the experiment did not influence this effect.

A greater proportion of dietary amino acid is converted into body lipids in obese rodents as compared with their lean littermates (Dunn and Hartsook, 1980). Thus, it might be thought that amino acid supplementation, in particular of glucogenic amino acids, would increase lipid retention by improving energy efficiency in both the FL and the LL. The results obtained indicate that the four glucogenic amino acids added to the experimental diets did not affect growth performance and body composition but reduced protein and energy efficiencies in both lines. In fact, in our experiments, some effects of amino acid supplementation may have been due to the increased total dietary protein level (equivalent to $1.4 \%$ ) (Leclercq, 1983).

The main features of the plasma free amino acid profiles of both lines are shown in figure 3. As in obese (ob/ob) mice (Chee et al., 1981) and obese humans (Felig et al., 1971a), fat chickens showed lower total plasma free amino acid levels than lean birds, whatever their nutritional status or diet. This difference was mainly due to glucogenic amino acids, the levels of which were 10 to $15 \%$ lower in the FL. The discrepancies between the two experiments in the different plasma free glucogenic amino acid levels could partly be explained by individual circadian and nutritional variations (Larbier et al., 1982). A greater liponeogenesis from these amino acids could explain their depletion. It has been shown, using 
${ }^{14} \mathrm{C}$-labelled leucine (Mamier et al., 1986), glutamic acid and alanine (Geraert et al., 1986) that $\mathrm{FL}$ birds incorporate more ${ }^{14} \mathrm{C}$ into body lipids. Furthermore, hepatic lipogenesis is greater in the FL than in the LL (Saadoun and Leclercq, 1983). Other mechanisms could be involved in this phenomenon, such as :

(i) increased gluconeogenesis from amino acids in FL chickens, as in the obese human (Felig et al., 1974b) and the obese Zucker rat (Koubi and Freminet, 1985) ; (ii) greater amino acid oxidation into $\mathrm{CO}_{2}$ as in obese mammals (Dunn and Hartsook, 1980).

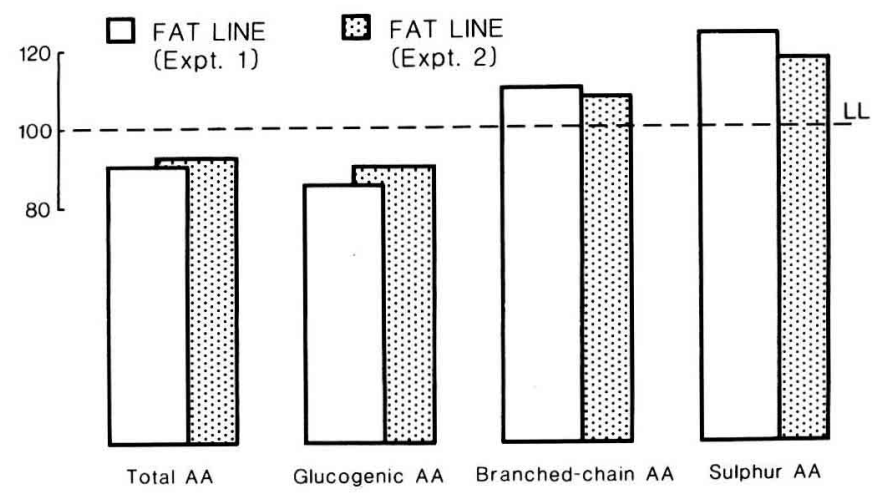

FIG. 3. - Relative plasma concentrations of free amino acids (AA) in FL and $L L$ chickens $(\mathrm{LL}=100)$. Experiments 1 and 2. Al/ treatments combined.

On the other hand, FL chickens exhibited higher plasma levels of free branched-chain and sulphur amino acids. Valine, leucine and isoleucine levels increased in fat birds as happens in obese (ob/ob) mice (Chee et al., 1981) which may indicate decreased muscular protein synthesis as in obese Zucker rats (Reeds et al., 1982) and obese diabetic $(\mathrm{db} / \mathrm{db})$ mice (Shargill et al., 1984), or a higher fractional rate of muscle protein breakdown as in 8-week obese rats (Dunn and Hartsook, 1980). Lastly, higher levels of cystine and methionine in the FL cannot be attributed to differences in feathering between the lines (Leclercq et al., 1980) and have yet to be explained.

The present results may be attributable to differences in glucose-insulin balance between the two lines. In both the fasted and fed state, FL chickens show hypoglycemia (present results) which is associated with normal or slightly increased plasma insulin levels (Touchburn et al., 1981 ; Simon and Leclercq, 1982). Indeed, insulin would stimulate amino acid transport and uptake (Guidotti et al., 1978) and hepatic lipogenesis in chickens (Joshi and Wakil, 1978). Nevertheless, some of our data are in contradiction with those reported by Felig and Wahren (1974b) who found in humans decreased levels of branched-chain amino acids and methionine and higher plasma glucogenic amino acid levels when insulin secretion was stimulated by glucose administration. These discrepancies cannot be explained at the present time. 
In conclusion, gluconeogenesis, liponeogenesis and oxidation of dietary amino acids in these two lines should be further investigated to obtain additional information on the mechanisms involved in fattening.

Reçu en mars 1987.

Accepté en septembre 1987.

Acknowledgements. - The authors are grateful to Mrs S. Guillaumin and Mr. G. Guy for assistance with the chemical analyses, to Mr. J.P. Harscoat for amino acid analyses and to Drs. M. Picard and J. Simon for helpful discussion.

Résumé. Influence d'une supplémentation alimentaire en acides aminés glucoformateurs sur les performances de croissance, la composition corporelle et les teneurs plasmatiques en acides aminés libres chez des poulets génétiquement maigres ou gras.

Deux expériences ont été réalisées pour étudier les effets du rationnement alimentaire, de l'état nutritionnel (jeûne de 16 heures ou alimentation à volonté) ou d'une supplémentation alimentaire en quatre acides aminés, alanine $(2 \mathrm{~g} / \mathrm{kg})$, thréonine $(2 \mathrm{~g} / \mathrm{kg})$, acide glutamique $(5 \mathrm{~g} / \mathrm{kg})$ et arginine $(5 \mathrm{~g} / \mathrm{kg})$, sur les performances de croissance, la composition corporelle et les teneurs plasmatiques en acides aminés libres de poulets génétiquement maigres (LL) ou gras (FL) entre 4 et 7 semaines d'âge. Nourris à volonté, les poulets gras ont consommé davantage que les maigres et ont montré des gains en lipides et protéines supérieurs. Rationnés, les poulets gras ont encore présenté une rétention lipidique plus importante mais un gain de protéines diminué. La supplémentation en acides aminés glucoformateurs n'a pas affecté significativement les performances de croissance et la composition corporelle. Néanmoins, l'indice de consommation a été légèrement amélioré alors que les efficacités énergétiques et protéiques globales ont été diminuées dans les deux lignées. Les poulets FL montrent une diminution de la somme des teneurs plasmatiques en acides aminés libres glucoformateurs et par contre des niveaux plasmatiques en acides aminés branchés et soufrés plus élevés que les poulets $L L$ et ce quel que soit le régime ou l'état nutritionnel.

\section{References}

CHEE K. M., ROMSOS D. R., BERGEN W. G., 1981. Effect of dietary fat on protein intake regulation in young obese and lean mice. J. Nutr., 111, 668-677.

CHU S. H. W., SAMONDS K. W., SERONDE J. Jr., HEGSTED D. M., 1978. Protein utilization and lysine metabolism in obese and non-obese growing rats. J. Nutr., 108, 567-577.

DUNN M. A., HARTSOOK E. W., 1980. Comparative amino acid and protein metabolism in obese and non-obese Zucker rats. J. Nutr., 110, 1865-1879.

FELIG P., WAHEREN J., HENDLER R., BRUNDIN T., 1974a. Splanchnic glucose and amino acid metabolism in obesity. J. clin. Invest., 53, 582-590.

FELIG. P., WAHREN J., 1974b. Protein turnover and amino acid metabolism in the regulation of gluconeogenesis. Fed. Proc., 33, 1092-1097.

GERAERT P. A., MAC LEOD M. G., JEWITT T. R., ANDERSON J., 1987. Energy and nitrogen metabolism in genetically fat and lean chickens. Proc. Nutr. Soc., 46, 34A (Abstr.).

GERAERT P. A., GUILLAUMIN S., LECLERCQ B., LARBIER M., 1986. Utilisation des acides aminés alimentaires à des fins énergétiques chez des poulets génétiquement maigres ou gras. In LARBIER M., 7th Eur. Poult. conf., Paris 24-28 Aug., WPSA Tours.

GUIDOTTI G. G., BORGHETTI A. F., GAZZOLA G. C., 1978. The regulation of amino acid transport in animal cells. Bioch. Biophys. Acta, 515, 329-366.

JOSHI V. C., WAKIL S. J., 1978. Hormonal regulation of hepatic fatty acid synthetase in chick embryo. Role of insulin. J. biol. Chem., 253, 2120-2125. 
KOUBI H., FREMINET A., 1985. Comparison of glycogen stores in 3- and 7-month old lean and obese Zucker rats under fed and fasted conditions. Comp. Biochem. Physiol., 81B, 103-110.

LARBIER M., HARSCOAT J. P., de REVIERS M., 1982. Individual variation in the content of free amino acids observed in the blood and skeletal muscle of chicks fed a single meal daily. $\mathrm{Br}$. Poult. Sci., 23, 7-13.

LARBIER M., LECLERCO B., 1983. Efficacité des protéines alimentaires et variation des acides aminés libre sanguins chez des poulets génétiquement différents pour l'engraissement. IV'Int. Symp. Métabolisme et nutrition azotés. Clermont-Ferrand (France), 5-9 sept. Ed. I.N.R.A. Publ. 1983, II (Les Colloques de I'I.N.R.A., $n^{\circ} 16$ ).

LECLERCQ B., 1983. The influence of dietary protein content on the performance of genetically lean or fat growing chickens. Br. Poult. Sci, 24, 581-587.

LECLERCQ B., BLUM J. C., BOYER J. P., 1980. Selecting broilers for low or high abdominal fat. Initial observations. Br. Poult. Sci., 21, 107-113.

LECLERCQ B., SAADOUN A., 1982. Selecting broilers for low or high abdominal fat : comparison of energy metabolism of the lean and fat lines. Poult. Sci., 61, 1799-1803.

MAMIER B., GERAERT P. A., LARBIER M., 1986. Metabolic utilization of leucine in a fat and a lean line of chicken. Comp. Biochem. Physiol., 83A. 735-737.

PULLAR J. D., WEBSTER A. J. F., 1977. The energy cost of fat and protein deposition in the rat. Br. J. Nutr., 37, 355-363.

RADCLIFFE J. D., WEBSTER A. J. F., 1978. Sex, body compositioni and regulation of food intake during growth in the Zucker rat. Br. J. Nutr., 39, 483-492.

REEDS P. J., HAGGARTY P., WAHLE K. W. J., FLETCHER J. M., 1982. Tissue and whole-body protein synthesis in immature Zucker rats and their relationship to protein deposition. Biochem J., 204, 393-398.

SAADOUN A., LECLERCQ B., 1983. Comparison of in vivo fatty acid synthesis of the genetically lean and fat chickens. Comp. Biochem. Physiol., 75B, 641-644.

SHARGILL N. S., OHSHIMA K., BRAY G. A., CHAN T. M., 1984. Muscle protein turnover in the perfused hindquarters of lean and genetically obese-diabetic $(\mathrm{db} / \mathrm{db})$ mice. Diabetes, 33 1160-1164.

SIMON J., LECLERCQ B., 1982. Longitudinal study of adiposity in chickens selected for high or low abdominal fat content : further evidence of a glucose-insulin imbalance in the fat line. $J$. Nutr., 112, 1961-1973.

SIMON J., LECLERCQ J., 1983. Relation entre insulinémie et adiposité dans deux lignées de poulets rendus maigres ou gras par sélection. Reprod. Nutr. Dévelop., 23, 443-451.

SNEDECOR G. W., COCHRAN W. G., 1956. Statistical methods (5th ed.). The lowa State College Press, Ames, IA.

TOUCHBURN S., SIMON J., LECLERCO B., 1981. Evidence of a glucose-insulin imbalance and effect of dietary and energy level in chickens selected for high abdominal fat content. $J$. Nutr., 111, 325-355. 